\title{
POLYCYCLIC AROMATIC HYDROCARBONS IN COCONUT KERNEL PRODUCTS
}

\author{
M.C.P. WIJERATNE ${ }^{1}$, U. SAMARAJEEWA ${ }^{2^{*}}$ and M. CHULA P. RODRIGO ${ }^{1}$ \\ 1 Institute of Fundamental Studies, Hantane, Kandy. \\ ${ }^{2}$ Faculty of Agriculture, University of Peradeniya, Peradeniya.
}

(Received: 19 January 1996; accepted: 06 September 1996)

\begin{abstract}
Eighty seven samples of coconut kernel products from Sri Lanka dried in the sun, in directheating kilns, and in indirect heating kilns were examined for polycyclic aromatic hydrocarbons (PAH) formed by combustion and thermal decomposition of organic substances in coconut shells. Analysis was done by the extraction of organic matter in dichloromethane followed by purification and quantification of PAH by HPLC using a fluorescent detector. The mean total PAH concentration in copra, coconut oil, copra meal and parings were $102 \pm 184$, $359 \pm 412,68 \pm 101$ and $109 \pm 164 \mu \mathrm{g} / \mathrm{kg}$ respectively. Some of the sun-dried copra samples did not contain any detectable PAH. Comparatively low PAH concentrations observed in Sri Lankan coconut kernel products were thought to be due to controlled combustion of shells with excess of air during drying of copra effected through the Standard Ceylon Copra Kiln which provides a relatively clean supply of hot air.
\end{abstract}

Key words: Coconut oil , coconuts, copra, curing, smoke-drying, PAH.

\section{INTRODUCTION}

Smoking of foods for drying and for imparting new organoleptic properties dates back to the time of discovery of fire. Smoke acts as a preservative and imparts flavour, colour and aroma to foods in addition to removing moisture. The smoke produced by controlled combustion of wood (primarily with limited oxygen) is a colloidal suspension of vapour, liquid droplets and solid particles which get deposited and adsorbed on food surfaces. More than 400 chemical compounds are present in wood smoke. ${ }^{1}$ They include acids (acetic, propionic, butyric and valeric) affecting flavour, shelf life and $\mathrm{pH}$ of foods, carbonyls that react with proteins to produce colour and phenols imparting flavour and demonstrating antibacterial, bactericidal and antioxidant properties. Smoke-curing changes texture and protein quality in protein-rich foods such as fish. ${ }^{2}$ A variety of methods are applied in smoke curing of foods. ${ }^{3}$

A major drawback of direct drying or smoke curing of foods is the deposition or production of polycyclic aromatic hydrocarbons (PAH). PAH are produced during combustion and pyrolysis of organic molecules. Possible mechanisms for the appearance of PAH in foods are reviewed by Dunn ${ }^{4}$ and Pariza ${ }^{5}$. PAH may

* Corresponding author. 
be adsorbed by foods directly from the smoke during processing or produced in the food itself due to action of heat ${ }^{5}$. PAH deposited in oilseeds during drying may transfer to vegetable oils. Vegetable oils are reported to contain PAH arising from processing ${ }^{6}$. Sorne of the PAH are highly carcinogenic and this raises concerns on smoke curing of foods (Table 1$)^{7}$. Among them benzo[a]pyrene and dibenzo $[a, h]$ anthracene are of proven high carcinogenicity. It is therefore important to determine the PAH concentrations in smoke cured coconut kernel products. No detailed work has been reported previously on PAH in coconut products. The present study examined sun-dried, smoke-dried and indirect kiln-dried coconut kernel products for their PAH. The objective was to determine the concentrations of $\mathrm{PAH}$ present in the edible coconut kernel products and understand the probable rnechanisms of contamination of coconut kernel products by $\mathrm{PAH}$.

\section{METHODS AND MATERLALS}

Samples: Samples of smoke-dried copra, sun-dried copra, smoke-dried parings, sun-dried parings, desiccated coconuts, coconut oil and copra meal (poonac) were collected from twenty coconut kernel processing mills in the coconut triangle bordered by the towns of Kurunegaia, Chilaw and Colombo and stored at $-4^{\circ} \mathrm{C}$ pending analysis.

Extraction of PAH: The oil and the PAH from the solid samples (10 g) were subjected to Soxhlet extraction using hexane $(250 \mathrm{ml})$ for $4 \mathrm{~h}$ at a siphon rate of 10-12 cycles per hour. The hexane was evaporated in vacuo maintaining a water bath at $65^{\circ} \mathrm{C}$. This was followed by drying at $70^{\circ} \mathrm{C}$ for $2 \mathrm{~h}$ in an oven.

The extracts of PAH (0.2-0.3 g) were made up to $10 \mathrm{ml}$ with hexane in volumetric flasks. The hexane solution $(1 \mathrm{ml})$ was passed through a Sep-pak (Bond Elute LRC, Varian Inc.) cartridge conditioned by eluting with $2 \mathrm{ml}$ of hexane. The PAH were eluted with $3 \mathrm{ml}$ of hexane- dichloromethane ( $3: 1$ ). The solvents were evaporated to dryness under a slow jet of nitrogen gas. The dry contents were dissolved in $500 \mu \mathrm{l}$ of acetonitrile-water (3:1) for analysis by HPLC. All solvents used were BDH 'hypersolv' HPLC grade.

Estimation of PAH: The HPLC system consisting of a Shimadzu model LC - 6A machine equipped with a model SIL-6A injector, solvent delivery system (model LC-6A), a fluorescence detector (model RF-551) with $298 \mathrm{~nm}$ excitation filter and a $439 \mathrm{~nm}$ emission filter were used. The reverse phase HPLC system, solvent program and peak integration parameters were controlled by a Shimadzu SCL-6A system controller and a CR 4A integrator. Samples were analyzed using Chrompack ChromSpher PAH glass cartridge column ( $20 \mathrm{~cm} \times 3 \mathrm{~mm}$ i.d.). 
PAH were separated at an ambient temperature of $(25 \pm 2)^{\circ} \mathrm{C}$ using a binary gradient elution program with a flow rate of $1 \mathrm{ml} / \mathrm{min}$ employing an initial mobile phase of $30 \%$ water in acetonitrile for $6 \mathrm{~min}$. The mobile phase was then gradually changed to $100 \%$ acetonitrile in $18 \mathrm{~min}$, held at 100\% acetonitrile for $4 \mathrm{~min}$ and allowed to drop down to $70 \%$ acetonitrile in $2 \mathrm{~min}$. The mobile phase was deaerated by bubbling helium gas at a pressure of $0.5 \mathrm{~kg} / \mathrm{sq} \mathrm{cm}$ throughout analysis. Fifty $\mu$ l samples of extracts or standards were injected at a time. The standard reference material 16476 from the National Institute of Standards and Technology, USA was injected after every 5 test samples. ${ }^{8}$

Minimum detection concentrations: Minimum detection concentrations of individual PAH were established by injecting $50 \mu \mathrm{l}$ of the primary standards and two diluted standardis (1:2 and 1:4) to obtain the relationship between peak area and concentrations. The noise level for the pure solvent at the same retention times for individual PAH was estimated and the standard deviation calculated. Five times the standard deviation was established as the minimum detection concentration for each of the PAH.

Validation of method: Ten percent of the samples analyzed in this study were cross checked by subjecting them to the identical analytical procedures at the Natural Resources Institute, UK.

\section{RESULTS}

\section{Minimum detection concentrations}

The abbreviations and carcinogenicity already in $\mathrm{use}^{7}$ and the minimum detection concentrations of PAH established in the present analysis are given in Table 1.

\section{Validation of Method}

The results obtained for the 10 samples in our analysis and those obtained at the Natural Resources Institute, UK gave a correlation coefficient of $0.87(\mathrm{p}<0.05)$ indicating the validity of the analytical procedure (Table 2 ).

\section{Field PAH concentrations}

The mean concentrations of PAH observed in coconut kernel products are summarized in Table 3 . In this study fresh coconuts immediately after splitting, and coconut kernels dehydrated inside the husk and shell by prolonged storage, were used as controls. They did not contain any PAH. The concentration of total PAH in the smoke-dried coconut kernel products in Sri Lanka is in the order of $100 \mu \mathrm{g} / \mathrm{kg}$. The unrefined oil showed a mean total PAH concentration of 
$359 \mu \mathrm{g} / \mathrm{kg}$. Extremely low to negligible concentrations of PAH were detected in desiccated coconuts which were dried using indirect heat (Table 3). A notable feature was the absence of PAH in the desiccated coconuts dried in the fluidizedbed-drier.

Table 1: Carcinogenicity and minimum detection concentrations of polycyclic aromatic hydrocarbons.

\begin{tabular}{llcl}
\hline PAH & Abbreviation $^{7}$ & Carcinogenicity $^{7}$ & $\begin{array}{c}\text { Detection } \\
\text { limit } \mu \mathrm{g} / \mathrm{kg}\end{array}$ \\
\hline Fluoranthene & $\mathrm{F}$ & - & 0.5 \\
Pyrene & $\mathrm{Py}$ & + & 0.2 \\
Benzo[a]anthracene & $\mathrm{BaA}$ & + & 3.6 \\
Benzo[b]fluoranthene & $\mathrm{BbF}$ & $-( \pm)$ & 2.1 \\
Benzo $[k]$ fluoranthene & $\mathrm{BkF}$ & +++ & 0.4 \\
Benzo $[a]$ pyrene & $\mathrm{BaP}$ & +++ & 2.8 \\
Dibenzo[a,h]anthracene & $\mathrm{DBahA}$ & $-(++)$ & 1.8 \\
Benzo[g, $h, i]$ perylene & $\mathrm{BghiP}$ & & 3.5 \\
\hline
\end{tabular}

+++ highly carcinogenic; ++ carcinogenic; + somewhat carcinogenic; - not carcinogenic; \pm uncertain;

\section{DISCUSSION}

\section{Field PAH concentrations}

The limited information published elsewhere on the PAH content in coconut products do not agree with the possible mechanisms of contamination occurring under processing conditions in Sri Lanka. Dennis et al. ${ }^{9}$ reported $79 \mu \mathrm{g} / \mathrm{kg}$ of total PAH in a single market desiccated coconut sample by extracting the PAH employing the same solvents as used in the present study and analysing by HPLC. However, the column system used by them was different. The values reported in the present study, even in poor quality desiccated coconuts are negligibly small. Although Dennis et al suggest that the mechanism of contamination of desiccated coconuts would have been similar to the mechanism of contamination of coconut oil, the validity of such a suggestion is questionable as desiccated coconut is not dried by direct hot air from the fuel in contrast to copra. 
Table 2: Comparison of PAH concentrations determined at the Natural Resources Institute, UK and in Sri Lanka $(\mu \mathrm{g} / \mathrm{kg})$

Sample No. $\quad \mathrm{F} \quad \mathrm{Py} \quad \mathrm{BaA} \quad \mathrm{BbF} \quad \mathrm{BkF} \quad \mathrm{BaP}$ DBahA BghiP Total

\begin{tabular}{|c|c|c|c|c|c|c|c|c|c|}
\hline Copra & 104 & 111 & 10 & 7 & 2 & 5 & 1 & 21 & 260 \\
\hline 35 & (135) & (16) & $(22)$ & (1) & (nd) & (nd) & (nd) & (1) & (175) \\
\hline Copra & 87 & 108 & 7 & 10 & 3 & 3 & 1 & 2 & 219 \\
\hline 48 & (18) & (4) & (nd) & (nd) & (nd) & (nd) & (nd) & (nd) & (22) \\
\hline Copra & 57 & 66 & 1 & 21 & 1 & 2 & 0 & 0 & 148 \\
\hline 86 & (5) & (28) & (1) & (nd) & (nd) & (4) & (1) & (nd) & (38) \\
\hline Poonac & 87 & 107 & 12 & 12 & 2 & 5 & 2 & 4 & 230 \\
\hline 12 & (72) & (136) & $(26)$ & (4) & (1) & (nd) & (nd) & (1) & (24) \\
\hline Parings & 125 & 5 & 0 & 9 & 0.3 & 0 & 1.5 & 1.3 & 142 \\
\hline 40 & (153) & (227) & (6) & (3) & (1) & (3) & (nd) & (2) & (395) \\
\hline $\mathrm{DC}$ & 69 & 70 & 5 & 7 & 3 & 6 & 2 & 7 & 168 \\
\hline 50 & (1) & (5) & (18) & (nd) & $(1)$ & (3) & (1) & (2) & (3) \\
\hline Copra & 37 & 29 & 0.4 & 1 & 1 & 2 & 1 & 0.2 & 71 \\
\hline 126 & (29) & (nd) & (nd) & (4) & (nd) & (nd) & (3) & (2) & (38) \\
\hline Oil & 62 & 55 & 6 & 4 & 2 & 4 & 6 & 5 & 144 \\
\hline 7 & $(91)$ & (nd) & $(28)$ & (nd) & (nd) & (nd) & (nd) & (nd) & (119) \\
\hline Oil & 278 & 732 & 22 & 18 & 5 & 21 & 2 & 117 & 1196 \\
\hline 65 & (286) & (297) & (338) & (70) & (14) & (48) & (84) & (86) & (1233) \\
\hline
\end{tabular}

$\mathrm{DC}=$ desiccated coconuts.Analytical results from Sri Lanka are given in parentheses.Correlation coefficient of the above samples was $0.87(\mathrm{p}<0.05)$.

nd $=$ not detectable. 
The PAH concentrations in coconut oil is expected to provide more representative information on the extent of contamination, as coconut oil is a more homogeneous product due to mixing in the storage tank as well as mixing of different grades of copra and parings deliberately by the millers prior to expulsion of oil. The mean concentration of total PAH observed in unrefined coconut oil in this study (Table 3) was 7-10 fold less compared to $2600-3700 \mu \mathrm{g} / \mathrm{kg}$ reported for unrefined coconut oils from elsewhere. ${ }^{10}$

Benzo $[a]$ pyrene, the most carcinogenic of the $\mathrm{PAH}$ is used as an index for assessment of safety of contaminated foods ${ }^{11}$ In vegetable oils varying Benzo[a]pyrene concentrations of $0.3-26.1 \mu \mathrm{g} / \mathrm{kg}^{12}, 0.1-4.1 \mu \mathrm{g} / \mathrm{kg}^{13}$ and a mean of $1.29 \mu \mathrm{g} / \mathrm{kg}^{9}$ have been reported. Larsson ${ }^{10}$ et al. reported $20-34 \mu \mathrm{g} / \mathrm{kg}$ of Benzo[a]pyrene in coconut oil. In the present study, however, the mean Benzo[a]pyrene concentrations observed in coconut oil was only $12 \mu \mathrm{g} / \mathrm{kg}$.

Refining of the coconut oil appears to remove the $\mathrm{PAH}$ almost totally as seen with the single sample we have examined. Although some authors have suggested possible production of $\mathrm{PAH}$ in palm oil during heat bleaching around $220-240^{\circ} \mathrm{C}$, no detectable concentrations of carcinogenic $\mathrm{PAH}$ had been reported from refined palm oil ${ }^{14}$. The observation by Rost ${ }^{14}$ agrees with our limited observation on refined oil.

Although detailed information on the methods of drying used in each of the coconut products was obtained from the producers at the time of collecting samples, the extent of smoke drying applied in each situation does not show a relationship with the estimated PAH concentrations (Table 4). The information from the producers is sometimes speculative and thus it is not possible to correlate the PAH concentrations observed in oil with the speculated methods of drying of the copra. The millers mix the copra of different grades at the point of oil expulsion making it further difficult to correlate method of drying with PAH concentrations.

The PAH observed in copra gave a mean value of $102 \mu \mathrm{g} / \mathrm{kg}$ indicating fairly low contaminations during smoking (Table 3). Only an occasional sample carried concentration above $100 \mu \mathrm{g} / \mathrm{kg}$. The total PAH for copra is much less compared with other smoked dried foods such as salmon, smoked with alder and juniper wood, containing concentrations of 439 and $271 \mu \mathrm{g} / \mathrm{kg}$ respectively ${ }^{10}$. Although distinct relationship of $\mathrm{PAH}$ concentrations with grade of copra, drying method of copra or any related parameters was not observed in this study, in general the grade 1 copra contained much lower concentrations of total $\mathrm{PAH}$. Some of the copra samples described as sun-dried did contain occasional high concentrations of mostly non-carcinogenic PAH. 
Table 3: PAH concentrations in commercial coconut kernel products ( $\mu \mathrm{g} / \mathrm{kg}$, dry weight).

\begin{tabular}{lllllll}
\hline Sample & F & BaA & BbF & BkF BaP DBahA BghiP Total
\end{tabular}

Copra $(n=34)$

$\begin{array}{lrrrrrrrrr}\text { mean } & 48 & 38 & 6 & 1 & 5 & 3 & 2 & 1 & 102 \\ \text { sd } & 87 & 101 & 12 & 3 & 27 & 5 & 7 & 3 & 184 \\ \text { range } & \text { nd } & \text { nd } & \text { nd } & \text { nd } & \text { nd } & \text { nd } & \text { nd } & \text { nd } & \text { nd } \\ & -355 & -566 & -49 & -14 & -161 & -24 & -36 & -11 & -428\end{array}$

Coconut oil $(n=19)$

$\begin{array}{lrrrrrrrrr}\text { mean } & 154 & 117 & 42 & 12 & 3 & 12 & 7 & 10 & 359 \\ \text { sd } & 186 & 137 & 82 & 19 & 5 & 8 & 19 & 21 & 412 \\ \text { range } & \text { nd } & \text { nd } & \text { nd } & \text { nd } & \text { nd } & \text { nd } & \text { nd } & \text { nd } & \text { nd } \\ & -605 & -430 & -338 & -70 & -16 & -58 & -84 & -86 & -1233\end{array}$

Copra meal $(n=15)$

$\begin{array}{lrrrrrrrrr}\text { mean } & 31 & 24 & 7 & 1 & 0 & 1 & 2 & 1 & 68 \\ \text { sd } & 43 & 43 & 14 & 2 & 1 & 2 & 4 & 2 & 101 \\ \text { range } & \text { nd } & \text { nd } & \text { nd } & \text { nd } & \text { nd } & \text { nd } & \text { nd } & \text { nd } & \text { nd } \\ & -148 & -136 & -53 & -5 & -2 & -8 & -16 & -6 & -273\end{array}$

Fresh/nut-dried coconut $(n=6)$

$\begin{array}{lrrrrrrrrr}\text { mean } & 0 & 1 & 0 & 0 & 0 & 0 & 0 & 0 & 1 \\ \text { sd } & 0 & 1 & 0 & 0 & 0 & 0 & 0 & 0 & 1 \\ \text { range } & \text { nd } & \text { nd } & \text { nd } & \text { nd } & \text { nd } & \text { nd } & \text { nd } & \text { nd } & \text { nd } \\ & -1 & -3 & -1 & \text { nd } & \text { nd } & \text { nd } & \text { nd } & \text { nd } & -4\end{array}$

Desiccated coconut $(n=5)$

$\begin{array}{lrrrrrrrrr}\text { mean } & 3 & 2 & 4 & 0.3 & 0.3 & 1 & 0.1 & 0.5 & 11 \\ \text { sd } & 3 & 2 & 7 & 0.2 & 0.4 & 1 & 0.2 & 1 & 12 \\ \text { range } & \text { nd } & \text { nd } & \text { nd } & \text { nd } & \text { nd } & \text { nd } & \text { nd } & \text { nd } & \text { nd } \\ & -5 & -5 & -18 & -1 & -1 & -3 & -1 & -2 & -31\end{array}$

Parings $(n=8)$

\begin{tabular}{lrrrrrrrrr} 
mean & 63 & 34 & 6 & 1 & 0.3 & 5 & 0.9 & 0.6 & 109 \\
sd & 107 & 73 & 8 & 1 & 0.5 & 5 & 1 & 0.6 & 164 \\
range & nd & nd & nd & nd & nd & nd & nd & nd & 7 \\
& -299 & -227 & -23 & -4 & -2 & -15 & -2 & -2 & -395 \\
\hline
\end{tabular}

$\mathrm{nd}=$ not detectable. 


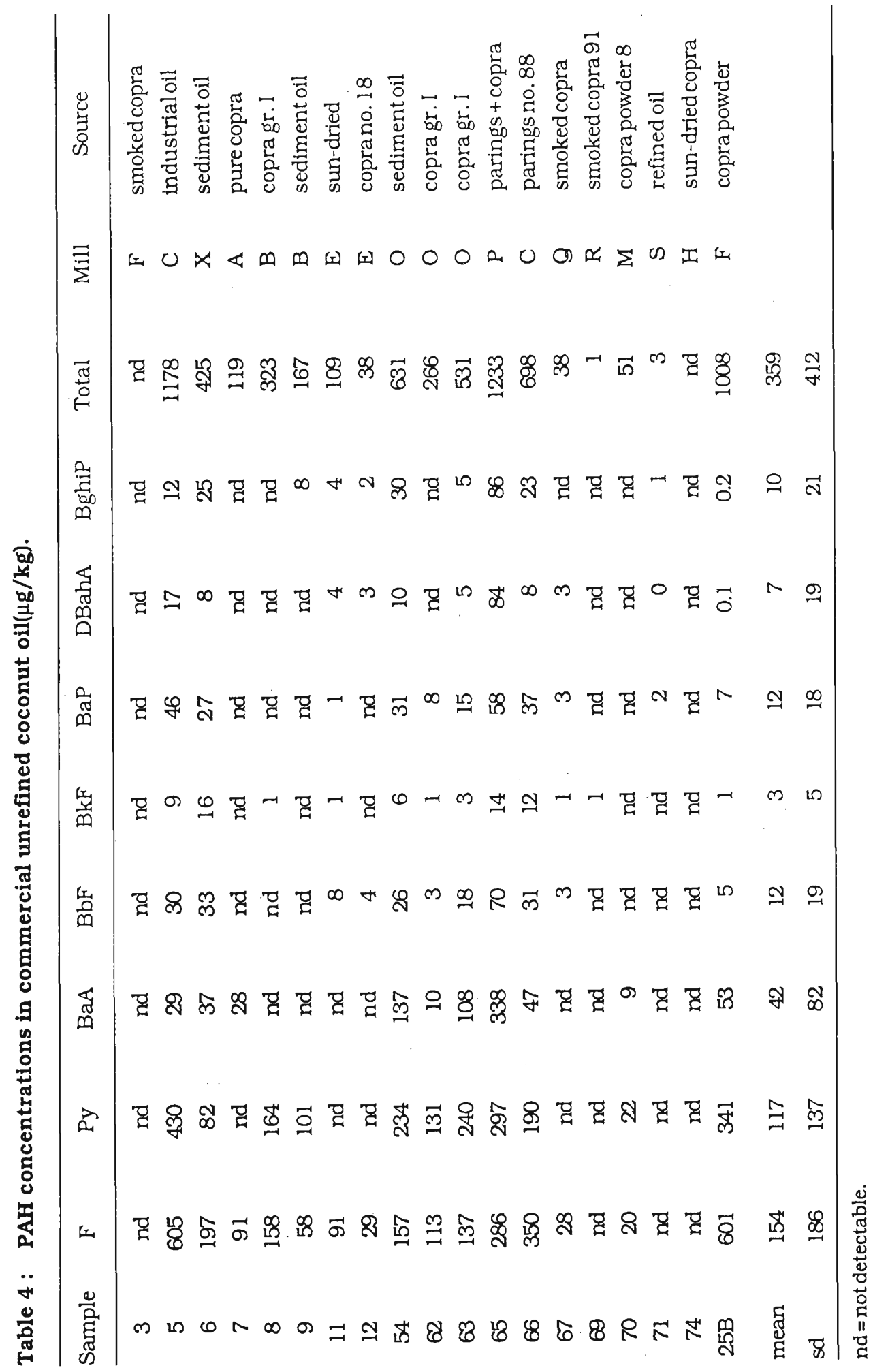


The copra meal (poonac) contained a mean PAH concentration of $68 \mu \mathrm{g} / \mathrm{kg}$ (Table 3) and this was lower than that of copra. Of the PAH in copra the bulk seems to move with the oil.

Parings, which is a byproduct of the desiccated coconut industry are sundried initially and may be smoke-dried when sufficient stocks accumulate. Smoke-dried parings contain the same concentrations of PAH as those of copra (Table 3). However, in totally sun-dried parings, the total PAH is less than $25 \mu \mathrm{g} / \mathrm{kg}$.

\section{Probable mechanism of PAH contamination}

The distribution pattern of total PAH between oil and copra meal suggested an increase in PAH during expulsion of oil. The copra contains $65 \%$ oil. The contents of total PAH observed in commercial coconut oil $(359 \mu \mathrm{g} / \mathrm{kg})$ and copra meal $(68 \mu \mathrm{g} / \mathrm{kg})$ when calculated back for copra based on weight distribution works out to be $273 \mu \mathrm{g} / \mathrm{kg}$. However, the mean of total PAH observed in commercial copra is $102 \mu \mathrm{g} / \mathrm{kg}$ only. This disparity indicates the probable production of PAH during expulsion of oil in addition to the PAH deposited during smoke curing. At the point of expulsion of oil in a screw press, the temperatures rise to 150 to $200{ }^{\circ} \mathrm{C}$. Thus deposition of $\mathrm{PAH}$ on copra during smoke-drying may not be the only mechanism of contamination.

\section{Heavy PAH}

The current tendency is to group the PAH into two categories based on available information on carcinogenicity ${ }^{15}$. The first group described as light $\mathrm{PAH}$ contains the non-carcinogenic compounds Fluoranthene, Pyrene and Benzo[a]anthracene. The second group of heavy PAH include Benzo[b]fluoranthene, Benzo[k]fluoranthene, Benzo[a]pyrene, Dibenzo[a,h]anthracene and Bénzo[g, $h, i]$ perylene.

A notable feature in coconut kernel products was that the presence of heavy PAH, namely Benzo[a]pyrene and Dibenzo[a,h]anthracene, accounts for less than $5 \%$ of the total PAH (Figure 1). The bulk of the PAH are non-carcinogenic, Fluoranthene and Pyrene which constitutes more than $95 \%$ of the total PAH of the coconut kernel products, as in most other foods ${ }^{4}$.

The concentrations of PAH in smoke-dried coconut kernel products in Sri Lanka appear to be much less than those reported for the similar smoke-dried products and vegetable oils. This may be associated with relatively 'clean' drying, coupled with well regulated combustion of the shell practiced in Sri Lanka. 

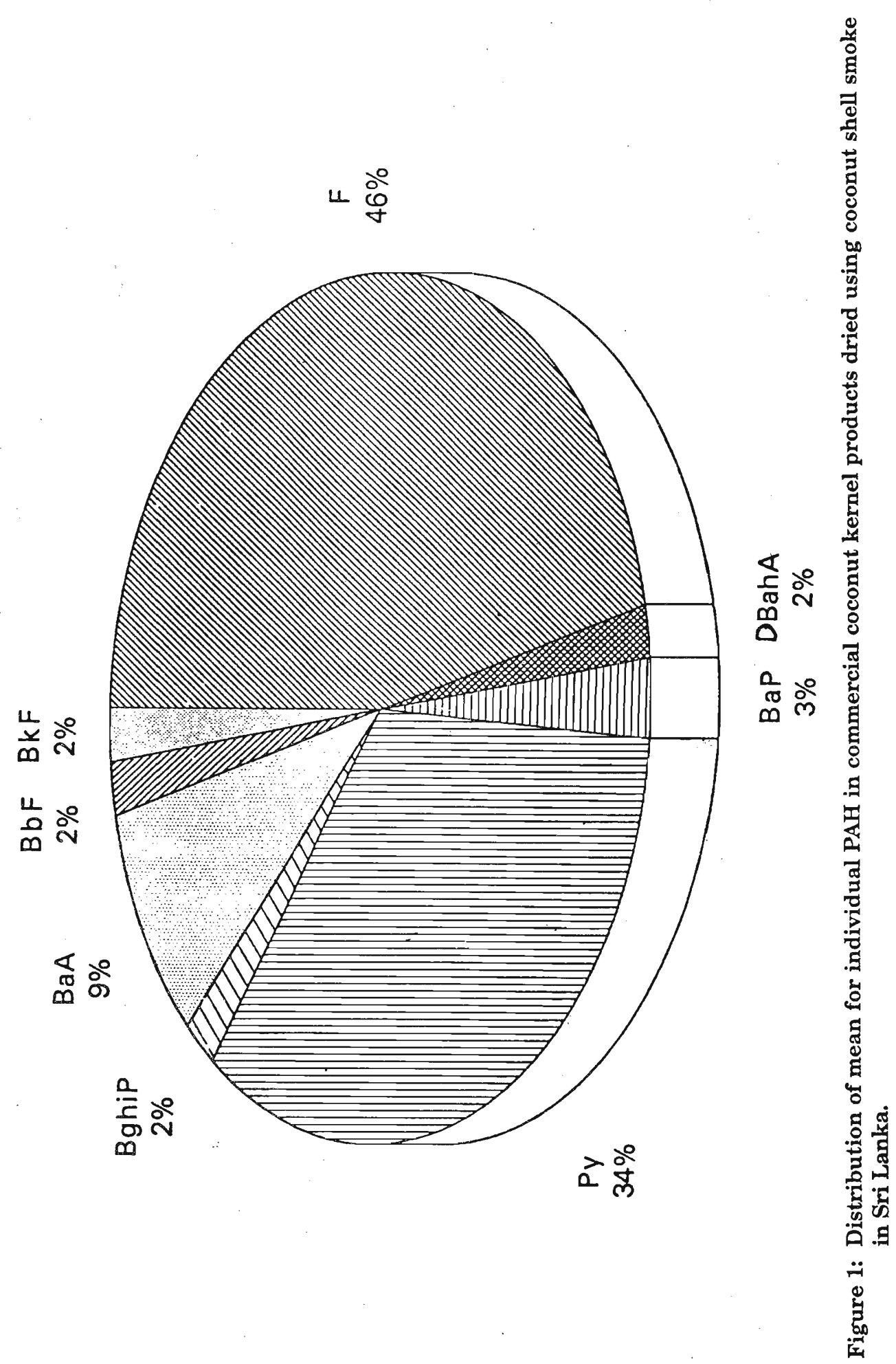


\section{Regulatory aspects and clasification}

Development of regulatory limits for total PAH and heavy $\mathrm{PAH}$ in foods is still at an elementary stage. Smoked-foods containing upto $3000 \mu \mathrm{g} / \mathrm{kg}$ of PAH are reported in the literature. ${ }^{10}$ In Germany, two tolerance limits of $25 \mu \mathrm{g} / \mathrm{kg}$ for total PAH and $5 \mu \mathrm{g} / \mathrm{kg}$ for Benzo[a]pyrene have already been suggested.

In the light of paucity of literature on the PAH in foods and the high variations of $\mathrm{PAH}$ concentrations noted even within a given food commodity, it is suggested to initially classify foods by their total PAH concentrations (Table 5). The table also gives the percent distribution pattern of $\mathrm{PAH}$ in coconut kernel products in Sri Lanka.

The suggested classification will assist a probable toxicological grading of foods and judicial improvement of processing conditions based on research for gradual reduction of $\mathrm{PAH}$ concentration to low or negative category.

Table 5: Suggested classification for total PAH in food commodities and the percent distribution of total PAH on coconut kernel products from Sri Lanka.

Category Range of $\mathrm{PAH} \mu \mathrm{g} / \mathrm{kg}$ Percent distribution of $\mathrm{PAH}$ on coconut kernel products

\begin{tabular}{lrc}
\hline Very high & $>2000$ & 0 \\
High & $251-2000$ & 17 \\
Medium & 26 & -250 \\
Low or negative & $<25$ & 36 \\
\hline
\end{tabular}

\section{Acknowledgements}

We thank Mr. David Evans of the Natural Resources Institute, UK for useful discussions and valuable guidance on the analytical method and for validation of the test method through the check sample programme. Technical assistance of Mrs. L. Dissanayake is acknowledged. This work was supported by a grant from the European Commission to Mr. Winstons Timmins who initiated and managed the project. 


\section{References}

1. Pszczola D.E. (1995). Tour highlights production and uses of smoke based flavors. Food Technology 49:(1) 70-74.

2. Bhuiyan A.K.M.A., Ackman R.G. \& Lall S.P. (1986). Effects of smoking on protein quality of Atlantic mackerel (Scomber scombrus). Journal of Food Processing \& Preservation 10: 115-126.

3. Caurie M., Lee T.C., Salomon M. \& Chichester C.O.(1974).Hot smoke fish curing. Journal of the National Science Council of Sri Lanka 2:77-86.

4. Dunn B.P. (1982). Polycyclic aromatic hydrocarbons (PAH). In: Carcinogens and mutagens in the environment. Vol. 1 Food products. (Ed. H.F. Stich) pp. 175-184. CRC Press. Boca Raton.

5. Pariza M.W. (1982). Mutagens in heated foods. Food Technology 36: 53-56.

6. Howard J.W.,Turicchi E.W., White R.H. \& Fazio T. (1996). Extraction and estimation of polycyclic aromatic hydrocarbons in vegetable oils. Journal of the Association of Official Analytical Chemists. 49: 1236-1244.

7. Gomaa E.A.,Gray J.I., Rabie S., Lopez-bote C. \& Booren A.M. (1993). Polycyclic aromatic hydrocarbons in smoked food products and commercial liquid smoke flavourings. Food Additives \& Contaminants 10(5): 503-521.

8. Southwell K.(1993). Determination of polycyclic aromatic hydrocarbons in oils and oil seeds. Paper: Seminar on contamination of oils. SCI Oils and Fats group, U.K. 12 May.

9. Dennis M.J., Massey R.C., Cripps G.,Venn I., Howarth N. \& Lee G.(1991). Factors affecting the polycyclic aromatic hydrocarbon content of cereals, fats and other food products. Food Additives \& Contaminants 8(4) : 517530 .

10. Larrson B.K., Ericsson A.T. \& Cervenka M. (1987). Polycyclic aromatic hydrocarbons in crude and deodorized vegetable oils. Journal of the American Oil Chemists Society 64: 365-370.

11. Rhee K.S. \& Bratzler L.J. (1970). Benzo(a)pyrene in smoked meat products. Journal of Food Science 35: 146-149. 
12. Welling P. \& Kaandorp B. (1986). Determination of polycyclic aromatic hydrocarbons $(\mathrm{PAH})$ in edible vegetable oils by liquid chromatography and programmed fluorescence detection. Zeitschrift fur Lebensmittel Untersuchung und Forschung 183: 111-115.

13. Speer A. \& Montag A. (1988). Polycyclic aromatic hydrocarbons in native vegetable oils. Fat Science \& Technology 90: 163-167.

14. Rost H.E. (1986). Influence of thermal treatments of palm oil on the content of polycyclic aromatic hydrocarbons. Chemistry \& Industry, 17 July, 612-613.

15. Timmins W.H. (1995). Polycyclic aromatic hydrocarbons (PAH) and copra. Proceedings of EC project seminar, Bogor, Indonesia, 24-27 July. 